\title{
PHYSICAL AND CHEMICAL CHARACTERISTICS OF A MEDITERRANEAN COASTAL MICROENVIRONMENT: THE "SALTY LAKE" OF AGHIOS NIKOLAOS (CRETE, GREECE)
}

\author{
N. MIHOPOULOS 1 \\ M. DASSENAKIS ${ }^{*}$ \\ G. ANASTASAKIS ${ }^{2}$ \\ M. SCOULLOS ${ }^{1}$
}

Received: 09/11/99

Accepted: $15 / 10 / 00$

\author{
1 University of Athens \\ Department of Chemistry, Division III \\ Panepstimioupolis Zografou, GR - 15771 GREECE \\ 2 University of Athens
}

Department of Historic Geology and Paleontology

Panepstimioupolis Zografou, GR - 15771 GREECE

*to whom all correspondence should be addressed

\section{ABSTRACT}

The present paper examines a small and deep $(53 \mathrm{~m})$ salty lake, as well as the adjacent harbor of Aghios Nikolaos (Crete). The survey was carried out in 1996. Physicochemical parameters indicated that the main characteristics of the system are the inflow of karstic water from underwater springs inside the lake and the permanent anoxic conditions prevailing in its deeper part, below the thermocline. Nutrient concentrations are very high throughout the water column of the lake. Ammonia is the main source of nitrogen in the summer, particularly below the thermocline, whereas nitrates have high concentrations during spring and autumn. The high levels of these nutrients in the adjacent to the lake harbor and coastal waters indicate clearly the impact of the lake to the marine ecosystem. Anthropogenic pollutants, such as aromatic hydrocarbons, show high concentrations above thermocline, at 5-10 m depths during all samplings. However no particular point source was identified. The presence of hydrocarbons contributes to ineffective oxygenation of the lake waters and facilitates the development of anoxia and the production of ammonia. The PAH concentrations at the sampling stations outside the lake are typical of marine environments, with relatively small oil-derived inputs, indicating the complex role of the system as a source and/or as a trap of PAHs.

KEY WORDS: Marine coastal environment, lake, harbor, anoxia, oil pollution.

\section{INTRODUCTION}

It is globally recognized that phenomena taking place in the interface between terrestrial and marine systems are particularly important as it concerns the transport of pollutants. Although the majority of the systems studied include rivers and "hot spots" due to coastal human activities, the significance of other small systems, such as lagoons, enclosed gulfs, fjords and coastal lakes, having interesting physicochemical characteristics, is also recognized, but less frequently studied. There is, therefore, need for environmental studies concerning these systems and the relative processes taking place therein, as they are vulnerable to ecological quality degradation. The above is clearly abundant in Mediterranean region (Helmer, 1977; GESAMP/UNESCO, 1987; Waldman and Shevah, 1993). 
In this study, physicochemical parameters, nutrient and petroleum hydrocarbon concentrations are examined in a characteristic Mediterranean coastal salty lake. Their influence upon the neighboring coastal area is also examined. The study area is the "Salty Lake" of Aghios Nikolaos, a karstic structure in the northern coast of the island of Crete, Greece (Figure 1). The lake displays the characteristic features of a collapsed doline. The shape of the doline is a rhombe with a maximum diameter of $137 \mathrm{~m}$ and its depth reaches $53 \mathrm{~m}$ (Figure 2) (Dermitzakis and Mariolakos, 1973). The lake occupies the central region of the coastal town of Aghios Nikolaos, a tourist resort. It is connected with the port through an artificial, small, shallow and narrow canal (1.2 m deep - $8 \mathrm{~m}$ wide), which allows the exchange of lake and sea water. This justifies the high salinity of the lake's waters, as well as its name "Salty Lake". Before the construction of the canal, in the beginning of the 20th century, the salinity of the system was considerably lower because of the many karstic spring waters inflows, even though seawater was entering the lake from the underground. The direction of the water's flow at the canal varies periodically from the port to the lake and vice versa. Changes in the direction are observed every several minutes (Dermitzakis and Mariolakos, 1973). The outflow of surface waters of lower salinity is followed, when the water level of the lake drops, by the inflow of surface sea waters. The great depth of the lake as compared to the shallow canal, plus the seasonal formation of strong pycnocline, does not allow the effective renewal of its deeper waters.

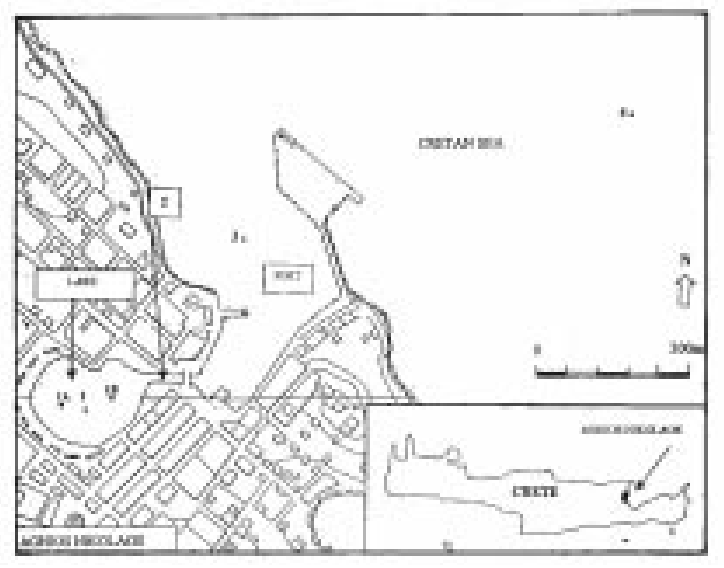

Figure 1. Studied area and sampling stations
Parts of the old drainage and sewage system of the town, as well as occasional overflow of the municipal sewage treatment plant (which is located at the northwestern side of the lake), add organic load and nutrients in the system. Possibly some of the karstic spring water inputs are also polluted. Diffused pollution sources and atmospheric inputs are not excluded.

\section{SAMPLING AND ANALYSIS}

Surveys were carried out in three periods (AprilJuly-November) during 1996. The study area and the sampling stations are shown in Fig. 1. Station 1 was located almost in the center of the lake where is the greater depth, about $50 \mathrm{~m}$. Station 2 was placed at the canal which has approximately $1.2 \mathrm{~m}$ depth. At this station double samples were taken: one when the water flew out of the lake and one when the water entered the lake. Station 3 (at $8 \mathrm{~m}$ depth) was placed in the harbor and station 4 (at $13 \mathrm{~m}$ depth) about 200 meters northeast, representing the open sea waters adjacent to the port. The sampling at station 4 in November was not possible due to extremely bad weather conditions. Additional physicochemical parameters were determined at two stations (1A and $1 \mathrm{~B})$ located at the west-central and east-central part of the lake respectively, which, however, correspond to significantly less deep sites (20 m depth). Temperature, dissolved oxygen and salinity were measured in situ employing Yellow Springs portable Instruments. [Dissolved Oxygen $\left(\mathrm{DO}_{2}\right)$ and Temperature (T): Y.S.I. - Model 57; Salinity (S): Y.S.I. Model 33; pH was measured by an ORION - 231 with $\mathrm{Ag} / \mathrm{AgCl}_{2}$ (99 SERIES pH

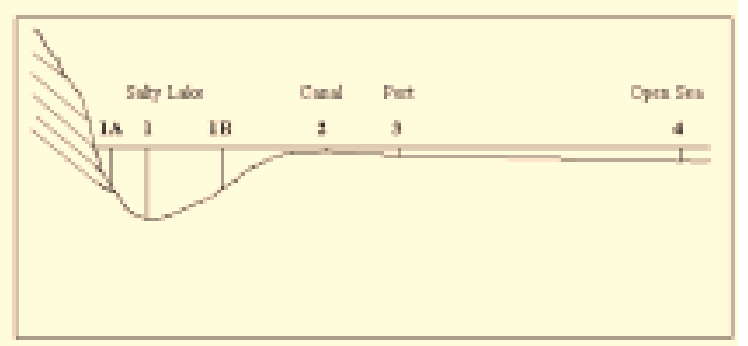

Figure 2. Vertical section of the studied area 
ELECTRODE)]. Water samples were taken with Hydro-Bios sampling bottles and put into 0.51 plastic and 11 dark-glass bottles for determining nutrients and total aromatic petroleum hydrocarbons (PAHs) respectively. The sampling vessel was a small fishing boat. Particular care was taken to avoid any sample contamination. Few drops of $\mathrm{HgCl}_{2}$ were added as preservative to all samples after collection. The samples kept in the plastic bottles were filtered through $0.45 \mu \mathrm{m}$ Millipore membrane filters using peristaltic pumps. Handling of all samples was carried out in a clean perspex chamber.

Nutrients were determined with standard spectrophotometric methods (Strickland and Parsons, 1968), employing a Hitachi (Model 100-60) spectrophotometer with a $5 \mathrm{~cm}$ length cuvette.

Dissolved/dispersed petroleum aromatic hydrocarbons (DDPH) were determined by using fluorescence spectroscopy (Keizer and Gordon, 1973) according to the IOC/UNEP (1984) procedure. The n-hexane extract was dried with dry $\mathrm{Na}_{2} \mathrm{SO}_{4}$ and concentrated to $5 \mathrm{ml}$ with a rotary evaporator maintained at low temperature. Fluorescence spectra of the concentrated n-hexane extracts
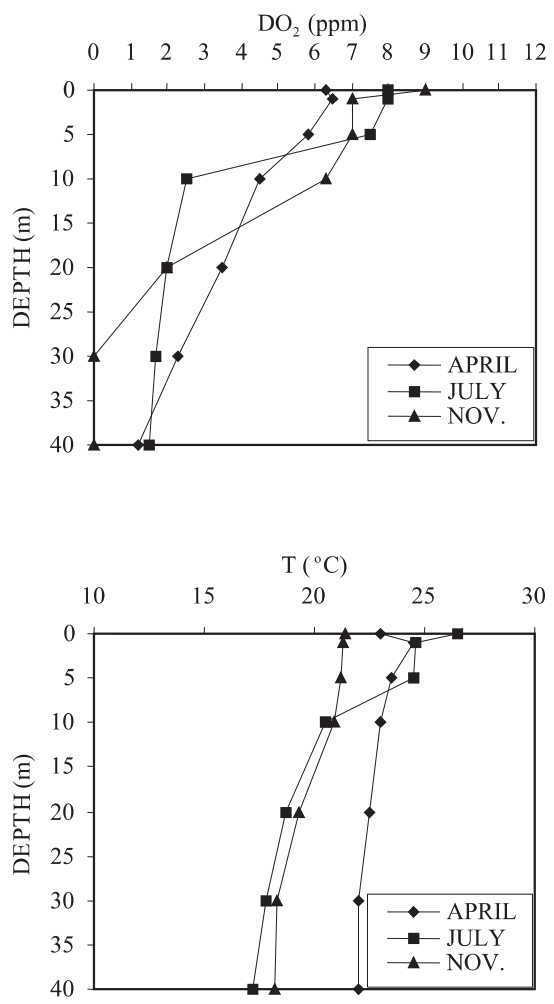

were measured on a Perkin-Elmer Double Beam spectrofluorimeter.

\section{RESULTS AND DISCUSSION Hydrological parameters}

The vertical distributions of dissolved oxygen, temperature, salinity and $\mathrm{pH}$ at stations $1,1 \mathrm{~A}, 1 \mathrm{~B}$, 2, 3 and 4 for the three samplings are shown in Figures 3 a to $f$ respectively.

The morphology of the doline is favorable for the development of stratification and anoxic conditions so the main characteristic of the system during all sampling periods was the considerable decrease of dissolved oxygen with increasing depth. The decrease is abrupt in the zone between 5 and $10 \mathrm{~m}$ particularly during summer and autumn, because the thermocline, which occurs at these depths is developed at the end of the spring and prevents effectively the vertical mixing. A low increase of dissolved oxygen from west to east (from station $1 \mathrm{~A}$ to $1 \mathrm{~B}$ ) is observed systematically in all samplings. This is due to the periodical influx of sea water from the port through the channel (station 2). Some very high concentrations of dissolved oxygen that were
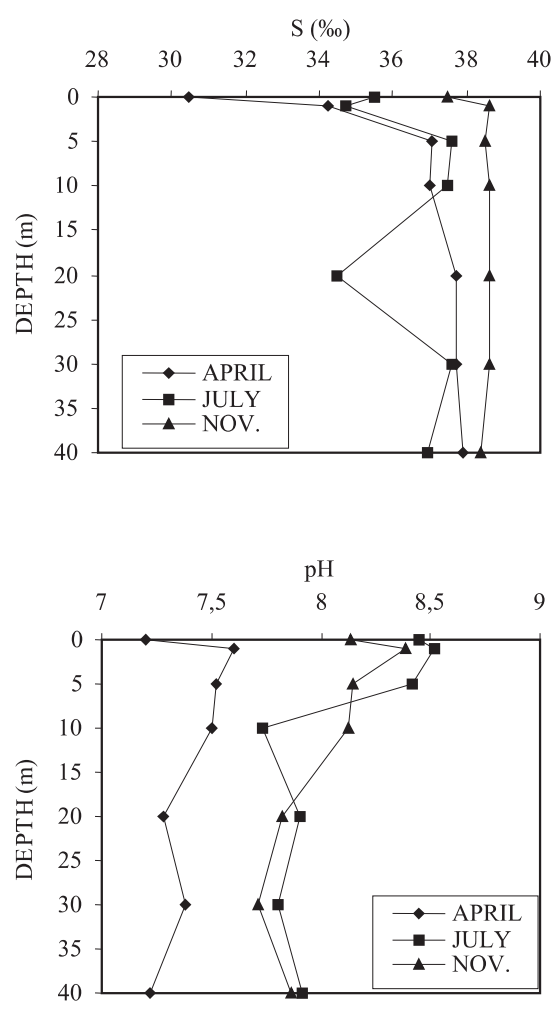

Figure 3a. Vertical distributions of dissolved oxygen $\left(\mathrm{DO}_{2}\right)$, temperature $(\mathrm{T})$, salinity $(\mathrm{S})$ and $\mathrm{pH}$ at station 1. 

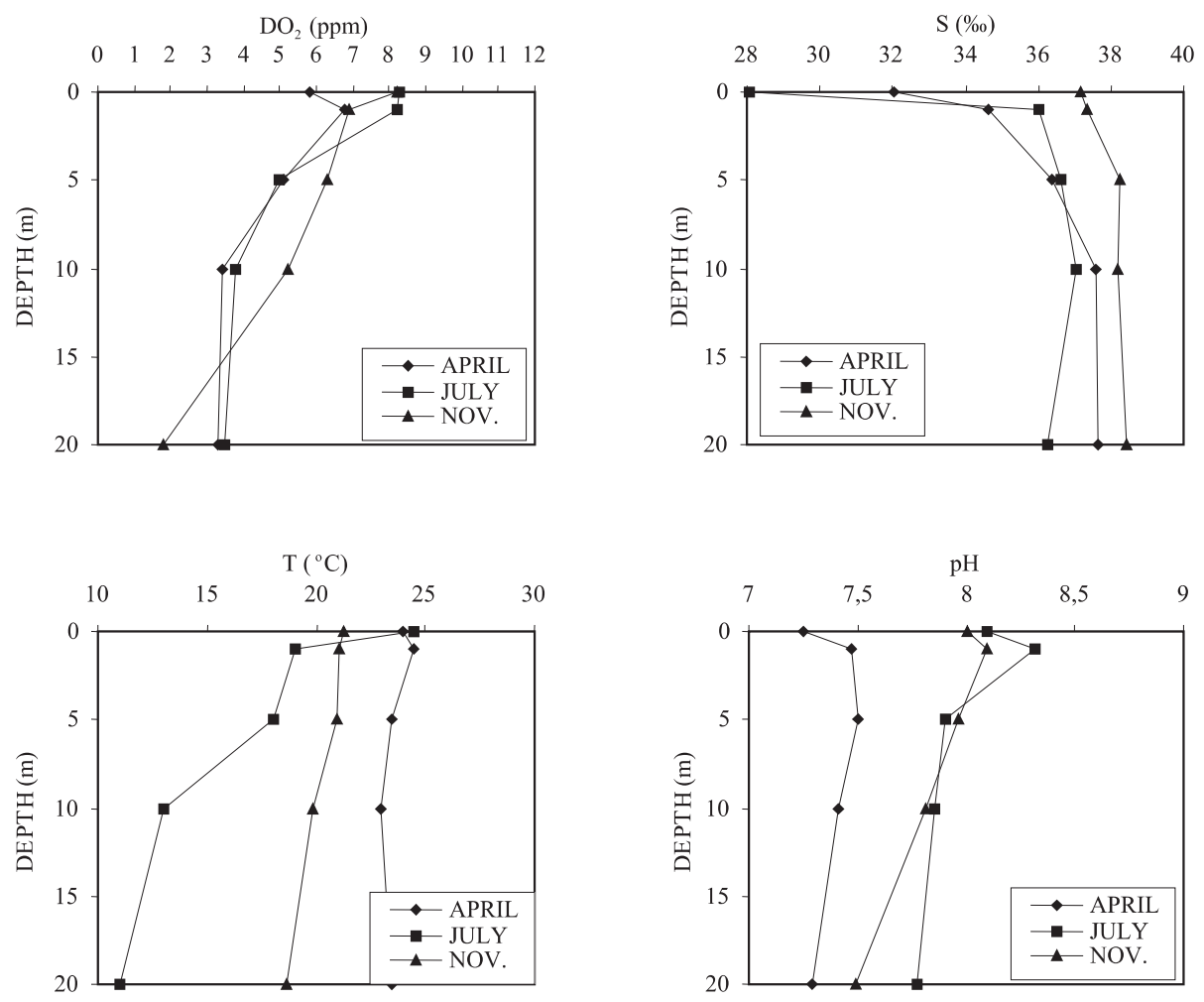

Figure $3 b$. Vertical distributions of dissolved oxygen $\left(\mathrm{DO}_{2}\right)$, temperature $(\mathrm{T})$, salinity $(\mathrm{S})$ and $\mathrm{pH}$ at station $1 \mathrm{~A}$.
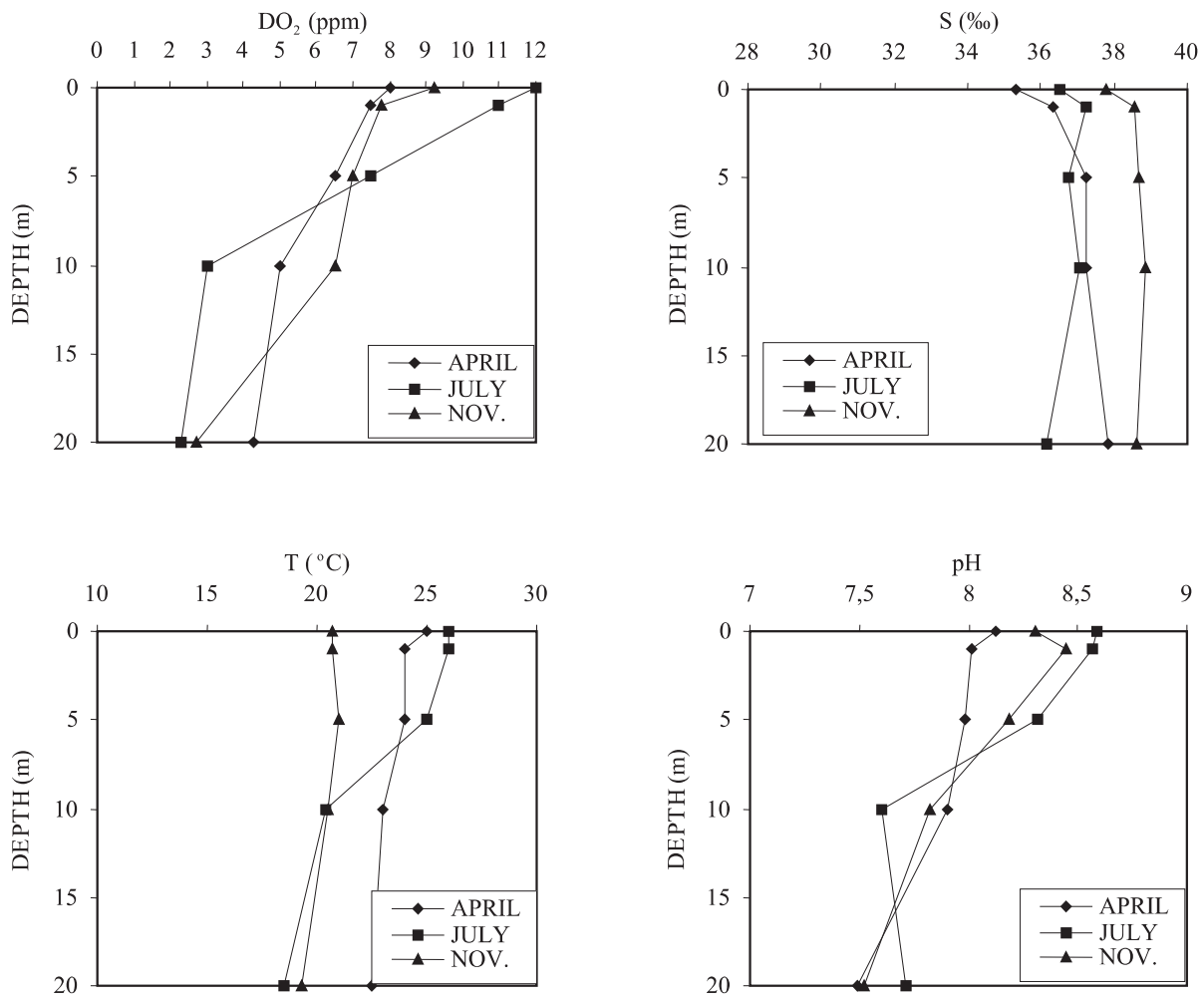

Figure 3c. Vertical distributions of dissolved oxygen $\left(\mathrm{DO}_{2}\right)$, temperature $(\mathrm{T})$, salinity $(\mathrm{S})$ and $\mathrm{pH}$ at station $1 \mathrm{~B}$. 

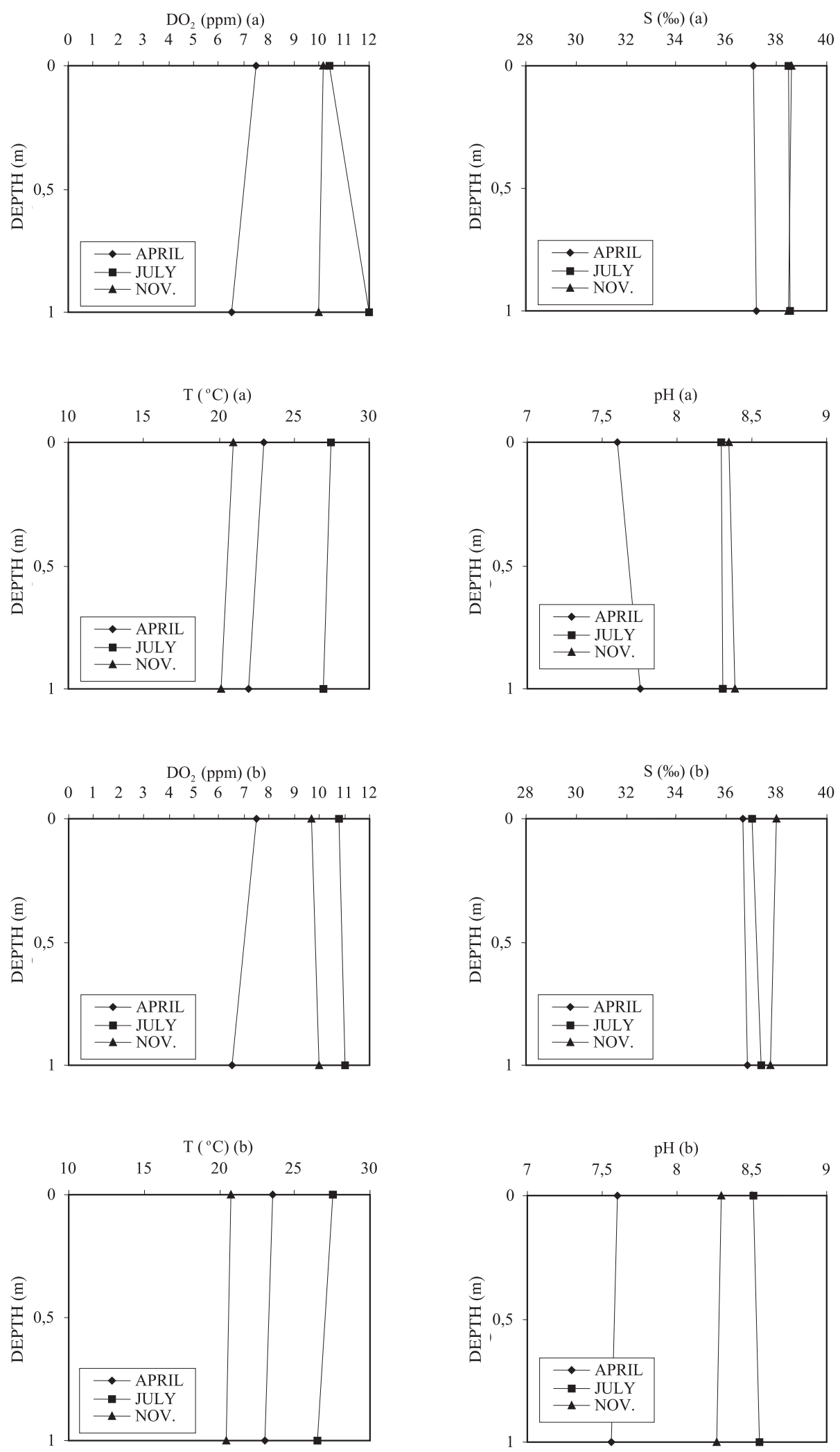

Figure $3 d$. Vertical distributions of dissolved oxygen $\left(\mathrm{DO}_{2}\right)$, temperature $(\mathrm{T})$, salinity $(\mathrm{S})$ and $\mathrm{pH}$ at station 2 . (a) The water has direction from the harbor to the lake, (b) The water has direction from the lake to the harbor. 

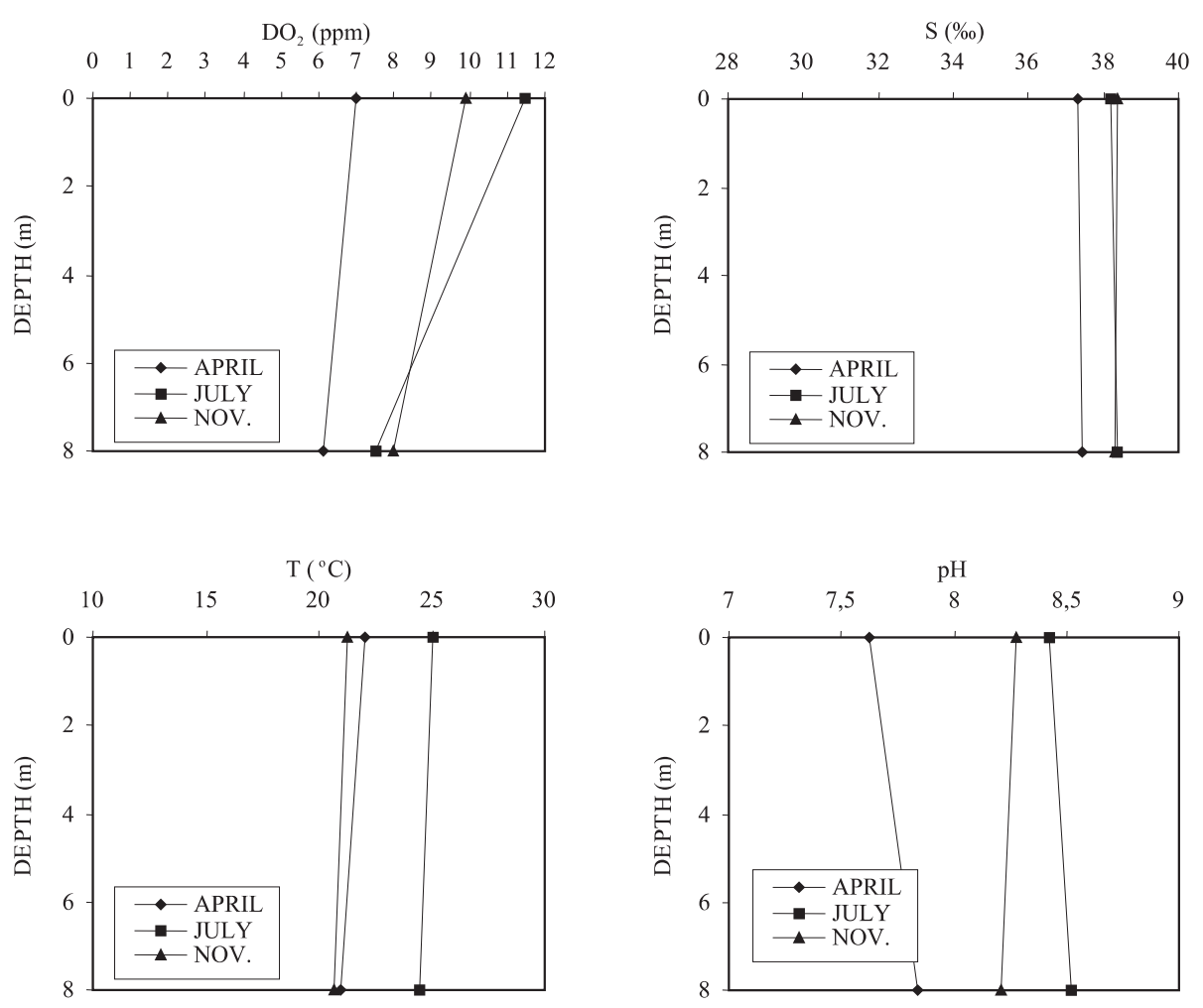

Figure 3e. Vertical distributions of dissolved oxygen $\left(\mathrm{DO}_{2}\right)$, temperature $(\mathrm{T})$, salinity $(\mathrm{S})$ and $\mathrm{pH}$ at station 3.

measured during daytime in summer (11.0-12.0 ppm), in the surface water layer (Fig. 3c, 3e and 3f) are probably due to hypersaturation effect which may caused by the strong north winds (etesians-meltemia), or by photosynthetic activities. Increased dissolved oxygen also justifies the very high values of $\mathrm{pH}(8.42-8.53)$ measured (stations 3 and 4). In general $\mathrm{pH}$ values vary between 7.22 and 8.59. Inside the lake, they were higher during July (m.v.: 8.4) in comparison with the two other samplings (Fig. 3a, 3b and 3c).

At the second sampling (July), the development of the thermocline has completed. It is localized between 5 and 10 meters and results in a very strong stratification of the lake water mass (Fig. $3 \mathrm{a}, 3 \mathrm{~b}$ and $3 \mathrm{c}$ ). A gradual temperature decrease from east to west (station 1B to station 1A) can be observed, due to the input of low temperature fresh waters at the west side of the lake. In July, the thermocline is identified at station $4\left(24.5^{\circ} \mathrm{C}\right.$ at $0 \mathrm{~m}$ and $21.0^{\circ} \mathrm{C}$ at $13 \mathrm{~m}$ ) (Fig. $3 \mathrm{f}$ ) even though there are not remarkable differences of temperature with depth at station $3\left(25.0^{\circ} \mathrm{C}\right.$ at $0 \mathrm{~m}$ and $24.5^{\circ} \mathrm{C}$ at $8 \mathrm{~m}$ ) (Fig. 3e).
The salinity of the lake water varies between 28.06 $\% o$ and $38.84 \%$ with values increasing gradually from west to east and from the surface to bottom (Fig. 3a, 3b and 3c). The reason for this distribution is the occurrence of karstic underwater springs along the west side of the lake, while to the east side there is the connection to the sea via the narrow channel. In restricted areas, near fresh water inflow, the salinity is reduced but the stratification of the lake water column is maintained mainly due to temperature gradients. The influx of fresh water although small, affects the salinity of the lake and the incoming water (station 2) has constantly higher levels ( $\mathrm{S}=37.07-38.62 \%$ ) than the one leaving the lake ( $\mathrm{S}=36.67-38.01 \%$ ) (Fig. 3d). The salinity levels at stations 3 and 4 seem to be typical of the open Mediterranean sea ( $\mathrm{S}=37.22$ $38.39 \%$ ) (Fig. 3e and 3f).

The above mentioned parameters lead us to the conclusion that the inflow of sea water in the lake due to the artificial channel has probably altered the character of the lake into a marine, rather, than a brackish microenvironment. In this case the main influence is that of the sea upon the lake than the other way round. 

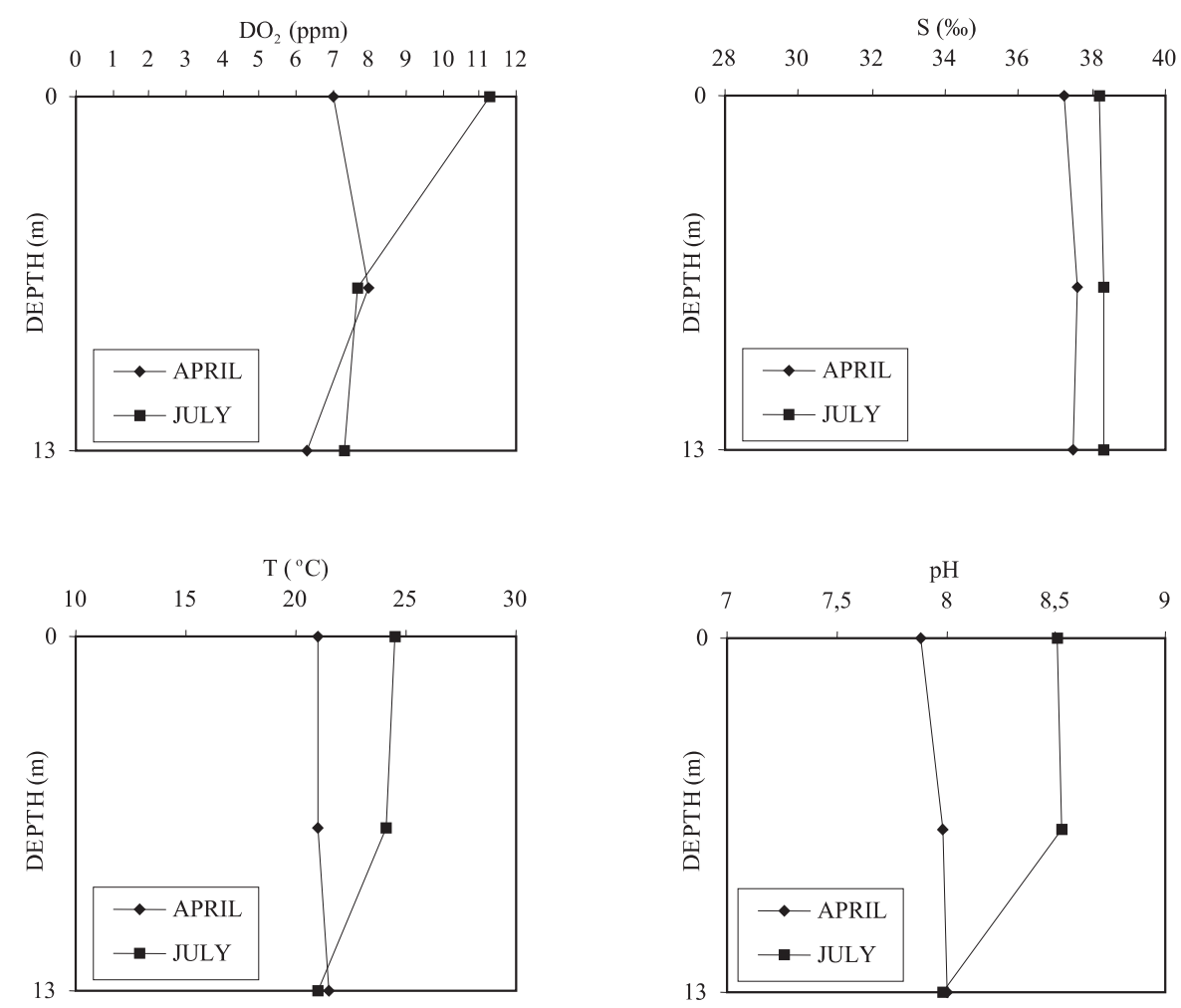

Figure $3 f$. Vertical distributions of dissolved oxygen $\left(\mathrm{DO}_{2}\right)$, temperature $(\mathrm{T})$, salinity $(\mathrm{S})$ and $\mathrm{pH}$ at station 4.

\section{Nutrients}

The concentrations of ammonia, nitrates, nitrites, phosphates and silicates for the three surveys are shown in Table 1.

In the Aghios Nikolaos salty lake, nitrates are the main nitrogenous species, mainly above the thermocline. Nitrate concentrations are very low $\left(<5 \mu \mathrm{mol} \mathrm{l}^{-1}\right)$ below the thermocline with simultaneous increase of ammonia, during July and November. It is known (Scoullos, 1980; Wollast, 1983) that oxygen depletion usually causes nitrates reduction to ammonia in small, enclosed, coastal Mediterranean systems with strong stratification. During the spring period nitrate concentrations are high throughout the water column, also below the thermocline, because the stratification is not so strong and some quantities of dissolved oxygen are present even near the bottom of the lake. Nitrate values are high at the upper layer of the lake and their impact is traced through the flashing out of lake water to the port through station 2, even though (as it is shown from Table 1) in April the water entering the lake has higher concentrations. High nitrate values are found also at station 4 indicating the influence of the lake water to the open sea. In turn, the low value $\left(3.5 \mu \mathrm{mol} \mathrm{l}^{-1}\right)$ at the first sampling shows the reciprocal impact of the open sea to the system, at least on its surface layer.

The distribution of nitrites at station 1 is almost the same as that of nitrates, but their concentrations are in general much lower. Ammonia is the prevailing nitrogenous species below the thermocline and mainly when the latter is strong. Then due to absence of oxygen, reduction of all other nitrogenous species to ammonia is observed. The maximum concentrations of ammonia were determined at the bottom of the lake in July and November, when the water stratification was maximum. The high values during summer and autumn at station 2 show that waters rich in ammonia leave the lake and enter the port and the open sea.

In general, the concentrations of the main nitrogenous species $\left(\mathrm{NO}_{3}^{-}\right.$and $\left.\mathrm{NH}_{4}^{+}\right)$display a reverse relationship, shown in Figure 4. The fact that this correlation is less prominent and clear during spring (April) might be attributed to the contribution of ammonia deriving from the first metabolic products 
Table 1. Nutrients concentrations. ${ }^{\text {a }}$

\begin{tabular}{|c|c|c|c|c|c|c|c|c|c|c|c|c|c|c|c|}
\hline \multirow[b]{2}{*}{ St. 1} & \multicolumn{3}{|c|}{$\mathrm{NO}_{3}^{-}$} & \multicolumn{3}{|c|}{$\mathrm{NH}_{4}^{+}$} & \multicolumn{3}{|c|}{$\mathrm{NO}_{2}^{-}$} & \multicolumn{3}{|c|}{$\mathrm{PO}_{4}^{3-}$} & \multicolumn{3}{|c|}{$\mathrm{SiO}_{4}^{4^{-}}$} \\
\hline & Apr. & Jul. & Nov. & Apr. & Jul. & Nov. & Apr. & Jul. & Nov. & Apr. & Jul. & Nov. & Apr. & Jul. & Nov. \\
\hline \multicolumn{16}{|c|}{ Depth $^{b}$} \\
\hline 0 & 35.1 & 34.4 & 66.1 & 3.00 & 2.46 & 3.33 & 0.62 & 0.08 & 0.40 & 0.13 & 0.48 & 0.15 & 21.0 & 24.8 & 42.6 \\
\hline 1 & 10.5 & 12.9 & 1.59 & 0.13 & 1.53 & 0.26 & 0.16 & 0.13 & 0.07 & 0.12 & 0.27 & 0.02 & 9.78 & 12.1 & 4.33 \\
\hline 5 & 10.2 & 3.62 & 8.86 & 0.09 & 6.50 & 2.53 & 0.14 & 0.13 & 0.47 & 0.11 & 0.09 & 0.02 & 25.0 & 13.1 & 47.0 \\
\hline 10 & 27.1 & 1.48 & 9.53 & 0.13 & 3.46 & 0.53 & 0.14 & 0.52 & 0.63 & 0.12 & 0.15 & 0.27 & 23.0 & 38.1 & 47.6 \\
\hline 20 & 76.7 & 5.87 & 1.48 & 3.41 & 13.2 & 7.00 & 0.28 & 3.13 & 0.02 & 0.19 & 0.54 & 1.58 & 29.6 & 57.5 & 167.6 \\
\hline 30 & 13.3 & 0.74 & 1.38 & 4.09 & 5.69 & 12.0 & 0.54 & 0.13 & 0.12 & 0.12 & 9.42 & 2.23 & 33.4 & 54.6 & 166.4 \\
\hline 40 & 16.1 & 1.93 & 1.45 & 3.41 & 16.4 & 24.1 & 0.34 & 0.19 & 0.05 & 0.13 & 1.59 & 3.61 & 34.6 & 58.3 & 197.6 \\
\hline \multicolumn{16}{|l|}{ St. 2} \\
\hline \multicolumn{16}{|l|}{ Depth } \\
\hline $0 \mathrm{c}$ & 23.8 & 12.8 & 18.6 & 1.59 & 6.61 & 6.50 & 0.18 & 0.38 & 0.31 & 0.11 & 0.36 & 0.21 & 20.0 & 15.8 & 28.1 \\
\hline $1 \mathrm{c}$ & 19.9 & 10.1 & 21.0 & 0.77 & 4.39 & 6.66 & 0.28 & 0.32 & 0.29 & 0.11 & 0.28 & 0.14 & 16.4 & 16.0 & 30.7 \\
\hline $0 \mathrm{~d}$ & 12.5 & 45.7 & 59.6 & 0.22 & 10.7 & 11.4 & 0.30 & 0.38 & 0.42 & 0.11 & 0.26 & 0.18 & 9.89 & 19.1 & 39.7 \\
\hline $1 d$ & 12.0 & 41.6 & 38.5 & 0.72 & 9.32 & 8.72 & 0.22 & 0.29 & 0.38 & 0.10 & 0.28 & 0.19 & 10.4 & 19.0 & 37.9 \\
\hline \multicolumn{16}{|l|}{ St. 3} \\
\hline \multicolumn{16}{|l|}{ Depth } \\
\hline 0 & 15.6 & 10.2 & 15.8 & 0.22 & 3.23 & 4.10 & 0.14 & 0.22 & 0.21 & 0.12 & 0.11 & 0.13 & 7.73 & 5.33 & 20.4 \\
\hline 8 & 3.42 & 2.81 & 4.38 & 0.63 & 5.46 & 4.82 & 0.14 & 0.19 & 0.20 & 0.11 & 0.13 & 0.15 & 2.14 & 2.16 & 12.6 \\
\hline \multicolumn{16}{|l|}{ St. 4} \\
\hline \multicolumn{16}{|l|}{ Depth } \\
\hline 0 & 3.50 & 8.72 & - & 1.45 & 2.18 & - & 0.06 & 0.09 & - & 0.12 & 0.12 & - & 3.09 & 3.21 & \\
\hline 7 & 11.1 & 4.31 & - & 0.54 & 2.49 & - & 0.06 & 0.11 & - & 0.12 & 0.12 & - & 2.20 & 1.98 & \\
\hline 13 & 11.8 & 5.07 & - & 0.72 & 1.54 & - & 0.06 & 0.09 & - & 0.14 & 0.14 & - & 2.03 & 2.09 & \\
\hline
\end{tabular}

Concentration mean values in Cretan Sea $\left(\mathrm{NO}_{3}^{-}: 0.78, \mathrm{NH}_{4}^{+}: 0.28, \mathrm{NO}_{2}^{-}: 0.03, \mathrm{PO}_{4}^{3^{-}}: 0.06, \mathrm{SiO}_{4}^{4^{-}}: 1.83\right)$

(Kucuksezgin et al., 1995; Tselepides et al., 1997)

a Concentrations are given in $\mu \mathrm{mol} \mathrm{l}^{-1}$

${ }^{\mathrm{b}}$ Depth is given in meters

c The water has direction from the harbor to the lake

d The water has direction from the lake to the harbor

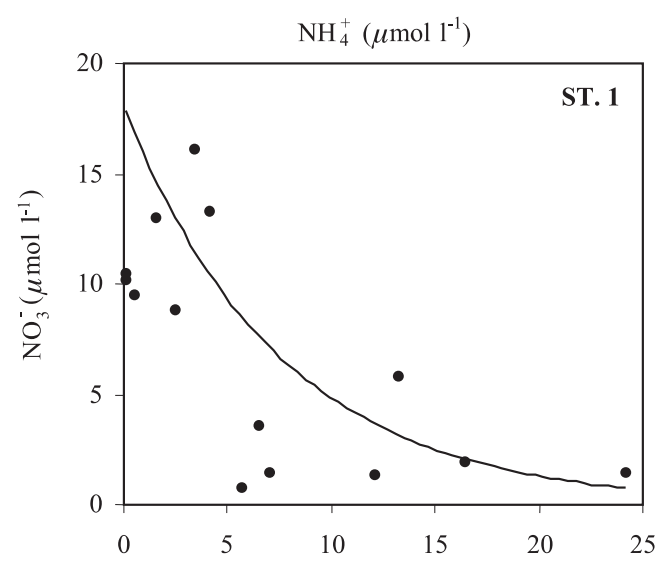

Figure 4. Correlation between nitrates and ammonium at station 1. 
of plankton after the spring bloom (Scoullos, 1983). The concentrations of phosphates and silicates increase with depth. This is more apparent in periods of high stratification (July, November), as it becomes evident from Table 1 . The values of silicates are very high at greater $(>10 \mathrm{~m})$ depths at station 1 because the anoxic conditions facilitate the dissolution of silicates from minerals and dead diatoms in addition to the already dissolved silicon (Scoullos, 1980) contributed by the karstic springs inside the lake, mainly in November during the due to rainfall. The reduction of $\mathrm{SiO}_{4}^{4-}$ at $1 \mathrm{~m}$ depth is probably due to consumption just below the surface from phytoplankton. These high concentrations influence in a clear way the harbor area (station 3) and the open sea waters (station 4) through the channel (station 2). The above is supported by the comparison of nutrients' values at station 4 with the mean values in oligotrophic Cretan sea (Kucuksezgin et al., 1995; Tselepides et al., 1997).

Table 2 shows that there is a significant difference between the relatively high values of total nitrogen at the surface of the lake $(0 \mathrm{~m})$ and those at 1 $\mathrm{m}$ depth. Atmospheric inputs may play a role in the observed enrichment of the surface microlayer, additionally to the biological activities that lead to the decrease of the concentrations at the subsurface layer. Furthermore $\Sigma \mathrm{N} / \mathrm{P}$ values show that the phosphorus seems to be the limiting factor for the development of the phytoplankton, mainly at the surface (enough phosphorous was

Table 2. Values of total nitrogen concentrations and nitrogen-phosphorous ratio.

\begin{tabular}{|c|c|c|c|c|c|c|}
\hline & \multicolumn{2}{|c|}{ April } & \multicolumn{2}{|c|}{ July } & \multicolumn{2}{|c|}{ November } \\
\hline & $\Sigma \mathrm{N}$ & $\Sigma \mathrm{N} / \mathrm{P}$ & $\Sigma \mathrm{N}$ & $\Sigma \mathrm{N} / \mathrm{P}$ & $\Sigma \mathrm{N}$ & $\Sigma \mathrm{N} / \mathrm{P}$ \\
\hline \multicolumn{7}{|c|}{ St. 1} \\
\hline \multicolumn{7}{|c|}{ Depth $^{\mathrm{a}}$} \\
\hline 0 & 38.8 & 298.4 & 36.9 & 77.0 & 69.8 & 465.5 \\
\hline 1 & 10.8 & 90.0 & 14.6 & 54.2 & 1.92 & 96.0 \\
\hline 5 & 10.4 & 95.0 & 10.2 & 113.8 & 11.8 & 59.3 \\
\hline 10 & 27.4 & 228.5 & 5.4 & 36.4 & 10.6 & 39.5 \\
\hline 20 & 80.4 & 423.1 & 22.2 & 41.1 & 8.5 & 5.3 \\
\hline 30 & 17.9 & 138.1 & 6.5 & 0.6 & 13.5 & 6.0 \\
\hline 40 & 19.9 & 153.0 & 18.5 & 11.6 & 25.6 & 7.0 \\
\hline \multicolumn{7}{|c|}{ St. 2} \\
\hline \multicolumn{7}{|c|}{ Depth } \\
\hline $0^{\mathrm{b}}$ & 25.5 & 231.8 & 19.8 & 55.0 & 25.4 & 120.9 \\
\hline $1^{\mathrm{b}}$ & 21.0 & 190.9 & 14.8 & 52.8 & 27.9 & 199.3 \\
\hline $0^{c}$ & 13.0 & 118.1 & 56.8 & 218.4 & 71.4 & 396.6 \\
\hline $1^{\mathrm{c}}$ & 12.9 & 129 & 51.2 & 182.8 & 47.6 & 250.5 \\
\hline \multicolumn{7}{|c|}{ St. 3} \\
\hline \multicolumn{7}{|c|}{ Depth } \\
\hline 0 & 15.9 & 132.5 & 13.7 & 124.5 & 20.1 & 154.6 \\
\hline 8 & 4.1 & 37.3 & 8.4 & 64.6 & 9.4 & 62.6 \\
\hline \multicolumn{7}{|c|}{ St. 4} \\
\hline \multicolumn{7}{|c|}{ Depth } \\
\hline 0 & 4.9 & 40.8 & 10.9 & 90.8 & - & - \\
\hline 7 & 11.6 & 96.6 & 6.8 & 56.6 & - & - \\
\hline 13 & 12.5 & 89.3 & 6.61 & 47.2 & - & - \\
\hline
\end{tabular}

a Depth is given in meters

b The water has direction from the harbor to the lake

c The water has direction from the lake to the harbor 
observed during winter in the deeper layers). This is one of the characteristics of many east Mediterranean systems (Krom et al., 1991, 1992; Thingstad and Rassoulzadegan, 1995).

\section{Total aromatic hydrocarbons}

DDPH levels at four sampling stations are shown in Table 3. The concentrations are in general, higher in the lake than at the harbor and station 4. Concentrations varied widely at station 1 depending on the depth and season from 0.07 to $97.8 \mathrm{ppb}$.
The very high levels found at the second and third sampling in the water column of the lake are not easily explained. Since contamination or errors in the determination are excluded the lake should be considered as a potential sink of DDPH discharged in it perhaps through the incoming karstic water and/or by fishing boats. Their accumulation may be partly to the slow degradation of hydrocarbons under the prevailing conditions of restricted water renewal and anoxia. The fact that the highest and simultaneously "anomalous" values $(3.43,97.8$ and $95.0 \mathrm{ppb})$ were found at 5-10 m

Table 3. Total aromatic petroleum concentrations ${ }^{\mathrm{a}}$

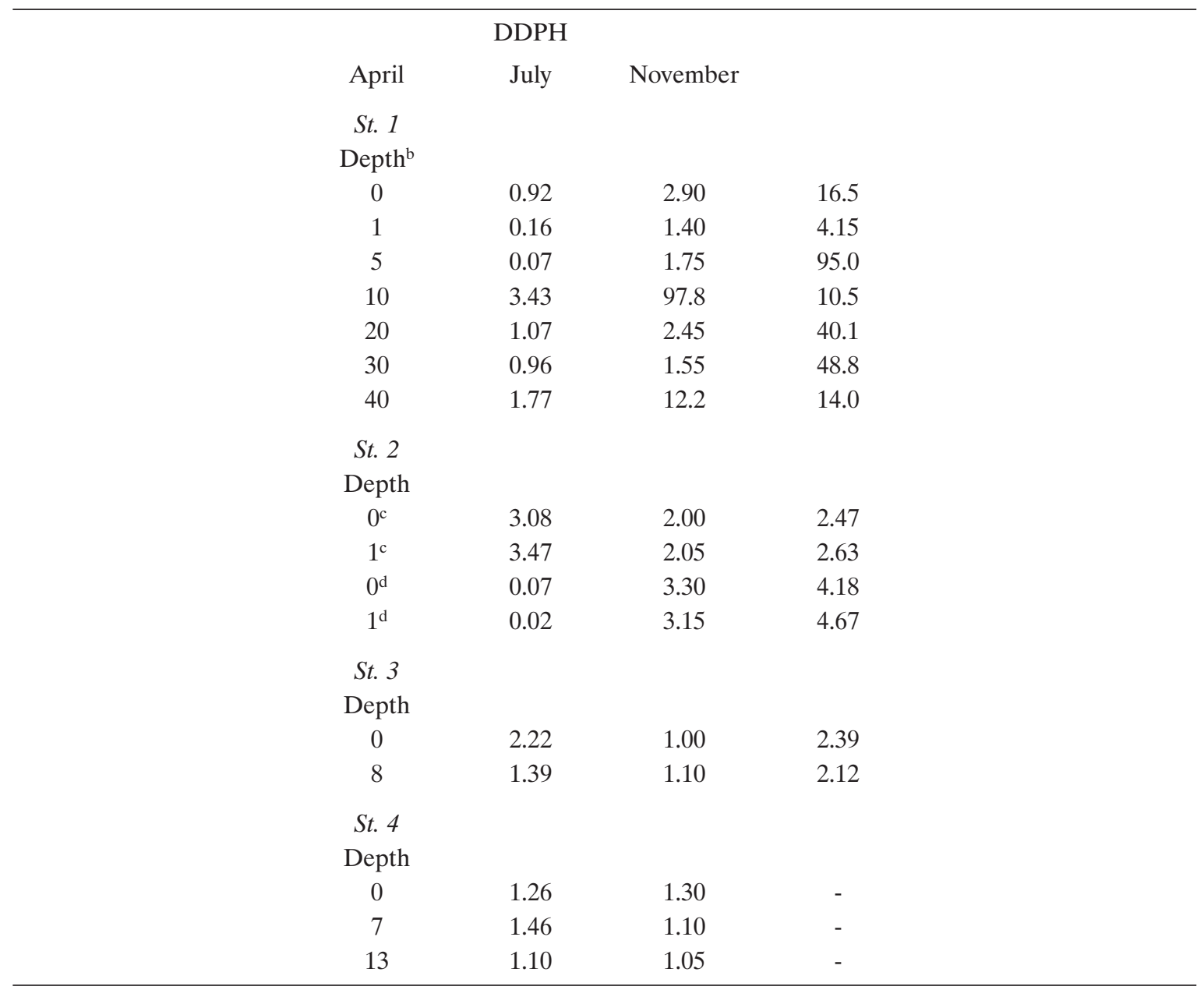

Concentration mean values in South Aegean: 3.20 (UNEP, 1988; UNEP, 1989)

${ }^{a}$ Concentrations are given in $\mathrm{ppb}$

${ }^{\mathrm{b}}$ Depth is given in meters

c The water has direction from the harbor to the lake

d The water has direction from the lake to the harbor 
depths of station 1 , during all samplings might not be a coincidence and might be attributed to a "unidentifiable" and probably underwater source of DDPH and eventually of nutrients since high nutrients levels were also found at the same depths. The maximum DDPH concentrations found at the thermocline contribute to the effective prevention of the diffusion of dissolved oxygen to the bottom layers of the water column.

Additionally the levels of DDPH determined in the harbor, though high, are not alarming despite the use of the port also by a ferryboat. Certain exchange of PAH's between lake and harbor is taking place as it is demonstrated from the values at station 2; there is a clear difference between inflow and outflow concentrations.

PAH's levels at station 4 are typical of coastal marine areas, and lower than those in other enclosed marine environments of Greece and the Adriatic, determined with the same analytical techniques (UNEP, 1988 and 1989).

\section{CONCLUSIONS}

The special environmental characteristics of the Aghios Nikolaos salty lake are due to its particular geomorphology and the human interactions in it. The man-made canal connecting the lake to the sea seems to be critical for its present character as salty lake. The system is a $53 \mathrm{~m}$ deep karstic doline having a structure that permits the development of a permanent and strong stratification with a pycnocline which prevents the renewal of the deeper waters of the lake and causes strong anoxic conditions below the thermocline. A significant phenomenon that contributes to the oxygen depletion is the accumulation of considerable concentrations of petroleum aromatic hydrocarbons, especially at the depths of 5-10 m. Their presence effectively prevents the diffusion of dissolved oxygen from surface waters to the bottom of the lake. Even though no specific source of the petroleum was identified, its presence at the system seems to be attributed to the inflow through the karstic springs, in addition to the operational pollution by the large number of fishing boats docked in the lake. The relatively low values found at the harbor and the coastal waters indicate that the contribution of the passenger ships, approaching Aghios Nikolaos' port once a day, to hydrocarbon pollution is of no significance.
Nutrient concentrations seem to be similar to those measured in other enclosed embayments of Greece (Dassenakis et al., 1994; Scoullos et al., 1996), although some even higher values of ammonia have been determined occasionally in the Gulf of Elefsis (Scoullos, 1980; Scoullos et al., 1983; Scoullos et al., 1987; Psyllidou-Giouranovits et al., 1997). Nitrates and ammonia are the main nitrogenous species above and below the thermocline, respectively. The absence of oxygen contributes to the generation of large amounts of ammonia. The latter together with considerable amounts of nitrates and silicates, which emanate from the bottom sediments enrich the upper layers of the water column and affect through the outflowing waters the port area and, to a certain extent, the open sea waters of the region. Some anomalies in the vertical distribution of nutrients probably are due to point sources (underwater springs) that cause variation in water supply and quality during the year.

It can be stated that the human intervention and especially the construction of the channel, which connects the sea and the lake, intensed the interaction between them. From the above measurements it is clear that there is an influence from the sea to the small lake system as it concerns the physicochemical parameters and mainly the salinity, as well as the dissolved oxygen at the surface layer. On the other hand there is also an obvious influence from the lake to the coastal waters adjacent to the port, as it concerns the nutrients. High levels and "anomalous" values of PAH's concentrations are focused in the lake. Their affection seems to be limited at the port.

In conclusion the present study demonstrated that discharges from land based sources and the vessels using the lake as a port are important and they should be controlled. Further research is needed particularly in order to identify source(s) of petroleum hydrocarbons and moreover to propose more specific remedial which will facilitate the oxygenation of the deep waters of the lake and the improvement of the overall local environmental conditions.

\section{ACKNOWLEDGMENTS}

The authors wish to thank Dr. Kyriakos Kambanis, Mr. Konstantinos Mastorakis and Mr. Michael Papadakis for their assistance during the samplings. 


\section{REFERENCES}

Dassenakis, M., Krasakopoulou, E. and Matzara, B. (1994), Chemical characteristics of Aetolikon Lagoon, Greece, after an ecological shock, Mar. Poll. Bull. 28, 427-433.

Dermitzakis, M. and Mariolakos, I. D. (1973), The lake of Aghios Nikolaos in East Crete: Physical geography and structural analysis, Annal. Geol. Pays Hellenique, 25, 373-396.

GESAMP/UNESCO (1987), Land/Sea Boundary Flux of Contaminants: Contributions from Rivers, Reports and Studies No. 32, 67-81.

Helmer, R. (1977), Pollutants from land based sources in the Mediterranean, Ambio, 6, 312-316.

IOC/UNEP (1984), Manual for Monitoring Oil and Dissolved / Dispersed Petroleum Hydrocarbons in Marine Waters and on Beaches, Manuals and Guides No. 13, UNESCO, Paris.

Keizer, P. D. and Gordon, D. C. (1973), Detection of trace amounts of oil in seawater by fluorescence spectroscopy, J. Fish. Res. Bd Canada, 30, 1039-1046.

Krom, M.D., Kress, N., Brenner S. and Gordon, L.I. (1991), Phosphorus limitation of primary productivity in the Eastern Mediterranean Sea, Limnol. Oceanogr. 36, 424-432.

Krom, M.D., Brenner S., Kress, N., Neori, A. and Gordon, L.I. (1992), Nutrient dynamics and new production in a warm-core eddy from the Eastern Mediterranean Sea, Deep Sea Res. 39, 467-480.

Kucuksezgin, F., Balci, A., Kontas, A. and Altay, O. (1995), Distribution of nutrients and chlorophylls in the Aegean Sea, Oceanologica Acta, 18, 343-352.

Psyllidou-Giouranovits, R., Pavlidou, A. and Georgakopoulou-Gregoriadou, E. (1997), Recent measurements of nutrients and dissolved oxygen in the Saronikos and the Elefsis Gulfs, In: Proceedings of the fifth National Conference of Oceanography and fisheries, 73-74, Kavala, Greece.

Scoullos, M. (1980), Oceanographic studies of the Gulf of Elefsis, Greece, In Proceedings of the first Greek - U.S. Working Conference of Oceanography related to Environmental Problems, 27-31, Aegina, Greece.

Scoullos, M. (1983), Nitrogen micronutrients in an intermittently anoxic basin, Vies J. Etud. Poll. 139-143, Cannes, France.

Scoullos, M., Alexiou, S. and Becacos-Kontos, T. (1983), Chlorophylls distributions in the polluted bay of Keratsini, Saronikos Gulf, Greece, Rapp. Comm. int. Mer Medit. 28, 77-78.

Scoullos, M., Dassenakis, M., Zeri, C., Papageorgiou, K. and Rapti, M. (1987), Chemical studies of main estuaries and coastal areas of Greece, Report for ENV-560GR E. C. Project.

Scoullos, M., Pavlidou, A., Dassenakis, M. and Beza, P. (1996), Environmental studies in a complex brackish system: the Bouliagmeni Lake, Greece, In: Proceedings of the third International Conference in Protection and Restoration of the Environment, 149-157, Chania, Greece.

Strickland, J. D.H. and Parsons, T.R. (1968), A Practical Handbook of Sea Water Analysis, Fish. Res. Bd Can. Bull. 167, 49-80.

Thingstad, T.F. and Rassoulzadegan, F. (1995), Nutrient limitations, microbial food webs, "biological C-pumps": suggested interactions in a P-limited Mediterranean, Mar. Ecol. Prog. Ser. 117, 299-306.

Tselepides, A., Polychronaki, T., Dafnomili, E., Plaiti, W. and Zivanovic, S. (1997), Distribution of Nutrients, Chloroplastic Pigments, POC, PON and ATP in the Cretan Sea (NE Mediterranean): Seasonal and interannual variability, In: Proccedings of the fifth National Symposium of Oceanography and Fisheries, 189-192, Kavala, Greece.

UNEP (1988), Assessment of the State of Pollution of the Mediterranean Sea by Petroleum Hydrocarbons, MAP, Technical Reports Series, No. 19, Athens.

UNEP (1989), State of the Mediterranean Marine Environment, MAP Technical Reports Series, No. 28, Athens.

Waldman, M. and Shevah, Y. (1993), Biodegradation and leaching of pollutants: Monitoring aspects, Pure and Applied Chem. 65, 1565-1603.

Wollast, R. (1983), The Major geochemical cycles and their interactions: Interactions in estuaries and coastal waters, SCOPE, Bolin, B. and Cook, R. B, (eds), Willey, New York. 